\title{
Influence of Environmental Pollutants on Water Quality and Biochemical Parameters of Fish Tissue
}

\author{
Amal S Mohamed ${ }^{1 *}$, Mohamed A El- Desoky ${ }^{2}$, Adel A El-Lahamy ${ }^{1}$ and Nahed S Gad ${ }^{1}$ \\ ${ }^{1}$ National Institute of Oceanography and Fisheries, Egypt \\ ${ }^{2}$ Faculty of Science, Cairo University, Egypt
}

*Corresponding author: Amal S Mohamed, National Institute of Oceanography and Fisheries, Egypt.

Received Date: March 21, 2020

Published Date: May 12, 2020

\begin{abstract}
Environmental pollution by toxicants has become one of the most important problems in the world. Water pollution problem is due to uncontrolled solid and liquid domestic, in addition to agrochemical contamination and lack of sustainable wastewater management that are becoming threats to living organisms and consequently to Human being. The continual loading of toxicants into our environment creates water pollution problems due to their direct toxic effect on aquatic biota. In addition, pollutants such as heavy metal can be incorporated into food chains and concentrated in aquatic organisms to a level that affects their physiological state. The impact of the environmental pollution on water quality and fish in aquatic ecosystem showed that there were clear differences between the concentrations of pollutants in water and fish tissues where, tissues showed different capacities for accumulating these pollutants. Environmental pollutants have harmful effects on the biochemistry of different tissues of fish. There were changes in the activities of antioxidant defense enzymes (superoxide dismutase and catalase), liver enzymes (ALT, AST and ALP), triglycerides, cholesterol, total proteins and total lipids in muscles of fishes which in turn affect meat Quality, the growth rate and fish production.
\end{abstract}

Keywords: Environmental pollution; Aquatic ecosystem; Superoxide dismutase; Catalase

\section{Introduction}

Environmental pollution represents a major problem in both developed and undeveloped countries [1]. In Egypt, it has been found that many environmental pollutants reach the natural water (rivers, seas, and lakes) through the industrial, agricultural and domestic effluents produced by human activities. The problems of environmental pollution and its deleterious effects on aquatic biota including fish received focused interest during the last few decades. The contamination of the aquatic environment with a wide range of pollutants has become a matter of concern. Increasing number and amount of industrial, agriculture and commercial chemicals discharged into the aquatic environmental having led to various deleterious effects on fish and a human who consumed it. Any change in the natural conditions of the aquatic medium causes several adjustments in fish. Heavy metals are the main culprit for these undesirable changes in water quality [2]. Due to their toxicity, long persistence, bioaccumulation and non-bio degradable properties in the food chain heavy metals constitute a core group of aquatic pollutants. Environmental pollution is caused due to the discharge of substances or energy into air, water, or land that may impart acute (short-term) or chronic (long-term) detriment to the quality of life. The impacts of pollution classified as primary and secondary. "Pollutants may cause primary damage which has directly identifiable impacts on the environment or secondary damage in the biological food chain that are noticeable over long periods" [3]. Pollution is now regarded as a global problem since pollutants can cross borders with the help of wind and water. Environmental pollution is insidious and its harmful effects only become apparent after periods of exposure. For this reason environmental monitoring is recognized as being vitally important in detecting the level and types of pollutants, and their source. Furthermore this monitoring helps to take measures to mitigate the effect in those seriously polluted areas. Within an aquatic ecosystem, a complex interaction of physical and biochemical cycles exists, anthropogenic stresses, particularly the interaction of 
chemicals into water may adversely affect many species of aquatic flora and fauna. Water quality criteria for protection of aquatic life may take into account only physic-chemical parameters which tend to protect and maintain aquatic life [4]. Regular water quality monitoring of the water resources is absolutely necessary to assess the quality of water for ecosystem health and hygiene, industrial use, agricultural use and domestic use [5]. The water quality evaluation may be a complicated practice in compound parameters causing numerous anxieties in general quality of water [6]. The fish performs all its physiological activities in the water breathing, excretion of waste, feeding and reproduction. Thus, water quality is the determining factor on the success or failure of fish biological functions. In the presence of environmental stress such as low dissolved oxygen, high temperature and high ammonia the ability of organisms to maintain its biological processes (metabolism, catabolism and reproduction) is reduced [7].

\section{Physicochemical characteristics of water}

Some Physicochemical parameters were studied in water. The most common parameters are:

\section{Temperature}

Water temperature is the one of the most basic physicochemical parameters because it varies temporally and spatially. It affects the ability of water to hold oxygen and the metabolic rates of aquatic organisms. Also, it affects the availability of trace metals which have an indirect effect on $\mathrm{P}^{\mathrm{H}}$ of water. It affects reproductive behavior and growth of fish. The solubility of solids increases with an increase in temperature while decrease for gases. Therefore, important gases for aquatic life decrease with increase in temperature. In general, temperature controls the rate of fundamental biochemical processes and thereby regulates organism attributes including development rate and survival [8].

\section{Transparency}

Transparency of water relates to the depth that light will penetrate water. In natural waters, it is important to know about the sunlight that penetrates in the water column because there are several water parameters that directly depend on sunlight. One of these parameters is the photosynthetic process that can only take place if the light intensity is above a minimum level [9]. The water quality in the shallow lake is affected by resuspension and settling of bottom sediments at least in two ways. First, sediments suspended in the water column decrease light penetration, yielding low Secchi disc values (inorganic turbidity), second, the sediments are capable of acting as internal source of nutrients [10].

\section{Electrical conductivity(EC)}

Electric conductivity (EC) is a measure of the ability of ions in a solution to carry electric current [11]. This ability depends on the presence of ions, their total concentration, mobility, valence and relative concentration and temperature. The warmer the water, the higher the conductivity. Conductivity in water is affected by the presence of inorganic dissolved solids such as chloride, nitrate, sulfate and phosphate anion or sodium, magnesium, calcium, iron and aluminum cautions. Organic compounds like oil, phenol, alcohol and sugar do not conduct electrical current very well and therefore have low conductivity when in water [12].

\section{Hydrogen ion concentration $\left(\mathrm{p}^{\mathrm{H}}\right)$}

$\mathrm{p}^{\mathrm{H}}$ reflects the concentration of the hydrogen ion and it is dependent on the interaction of numerous substances dissolved in water, photosynthetic activity of aquatic plants, respiration of aquatic organisms and decomposition of organic matter. The $\mathrm{p}^{\mathrm{H}}$ of natural water effects on biological and chemical reactions controls the solubility of metal ions and effects on natural aquatic life. Aquatic organisms differ as to the range of $\mathrm{p}^{\mathrm{H}}$ in which they flourish [12]. It can be toxic in itself at a certain level and also known to influence the toxicity of hydrogen sulfide, cyanides, heavy metals and ammonia [13].

\section{Dissolved oxygen (D0)}

Oxygen studies in water are very important since it is considered one of the most important limiting factors for the life of aquatic organisms which affect the biological processes of the aquatic organisms, the respiration of animal and oxidation of the organic matter in water and sediments. It is an important parameter in assessing the degree of pollution in which sewage pollution has been generally regarded as an organic pollution affecting fish and other aquatic life, principally through oxygen depletion. Bacteria consume oxygen as organic matter decay. As a result, an oxygen deficient environment can develop in lakes and rivers with the excess organic matter. These conditions can eventually lead to fish kills [12] and can result in reduced growth, disruption of life cycles, migration to avoid poor condition and death of benthic organisms [14]. DO is used as an indicator in most water quality studies and is suggested by EPA as an additional primary response variable in systems that have already experienced hypoxia [15].

\section{Biochemical oxygen demand (BOD)}

The BOD is the amount of oxygen consumed by bacteria in the decomposition of organic material. It also includes the oxygen required for the oxidation of various chemical in the water such as sulfides, ferrous iron and ammonia [12]. This parameter provides information on the potential for microbial respiration to breakdown the organic material present in the water which can lead to low DO and is a suggested cause of hypoxia [16].

\section{Chemical oxygen demand (COD)}

The chemical oxygen demand (COD) is the amount of oxygen required to oxidize the organic matter in waste water by use of a strong oxidant and to convert it to carbon dioxide and water [11]. COD test is used to assess the degree of pollution in the area under investigation. The value of COD is always higher than that of BOD5 because many organic substances can be oxidized chemically but not biologically [11]. 


\section{Ammonia, nitrite and nitrate}

Nutrients salts (ammonia, nitrite and nitrate) are essential to the metabolism and growth of aquatic organisms when its concentration increased; it's affected the biological equilibrium. In aquatic ecosystem nutrients salts have a greatly increased with time through a human activity which causes a problem with water quality [17]. In some areas, extensive use of mineral fertilizers has led to atmospheric pollution, greenhouse gas emissions (e.g. $\mathrm{N}_{2} \mathrm{O}$, very important for climate regulation), water eutrophication, and human health risks [18], thereby negatively affecting the regulating services of soil, air, and water quality [19]. Also, excess inputs of nitrogen can lead toeutrophication, which is the accelerated production of organic matter and the potential development of areas of low dissolved oxygen concentration (hypoxia). The consequences of hypoxia can include the death of benthic organisms, fish kills, reduced growth and disruption of life cycles. Other symptoms of eutrofication include, increases in turbidity, loss of submerged aquatic vegetation and changes in the food web [16].

\section{Heavy Metals in Water}

Water pollution is defined as an introduction by man, directly or indirectly, of substances or energy into the aquatic environment resulting in deleterious effects such as hazards to human health, hindrance of fish activities, impairment of water quality and reduction of climate amenities. Contamination also, caused when an input from human activities causes an increase of a substance in fresh or seawater, sediments and organisms above the natural background level for that area and for those organisms [20]. The water quality now is the main concern in all countries of the world and should at least be free from pathogenic organisms and toxic substances. Also, the quality of water depends on the location of the source and state of environmental protection in a given area [21]. The excessive contamination of aquatic ecosystems has evoked major environmental and health concerns worldwide [22] because the aquatic environment is the ultimate recipient of pollutants produced by natural and anthropogenic sources [23]. At the same time, uncontrolled wastewater discharges are causing immediate and long-term water quality health impacts on the users [24]. Heavy metals are present in the environment in different forms such as in solid phase and in solution, as free ions, or absorbed to solid colloidal particles. The heavy metal concentrations in the environment are due to natural sources (rock weathering, soil erosion, dissolution of water soluble salts) as well as anthropogenic source such as municipal wastewater, manufacturing industries, and agricultural activities [25]. Heavy metals are defined as those metals and metalloids generally considered to be of sufficient distribution and abundance to be in some way environmentally or biologically significant as a toxic substance. Also, the term heavy metal refers to any metallic chemical element that has a relatively high density and is toxic orpoisonous at low concentrations. The deleterious effects of metals on aquatic ecosystem necessitate the continuous monitoring of their accumulation in key species since it affords an indication of the temporal and spatial extent of the process and impact on organism's health [26]. Heavy metals including both essential and non-essential elements have a particular significance in ecotoxicologysince they are highly persistent and all have the potential to be toxic to living organisms [27]. Recent years have witnessed significant attention being paid to the problems of environmental contamination by a wide variety of chemical pollutants, including the trace metals Mendil \& Uluözlü [28]. Among environmental pollutants, metals are of particular concern; due to their potential toxic effect and ability to bio accumulate in aquatic ecosystems [29]. Copper, cadmium and lead are three elements that are among the most hazardousto human health. Lead pollution in water systems has seriously influenced the quality of life, especially in developing country. Lead is accumulated in tissues and may cause serious health problems for humans and animals. This metal inhibits biosynthesis and affects the kidneys, brain cells and the permeability the liver membrane, thereby reducing some of their functions. It can be accumulated in the body and can promote disturbances such as nausea, vomiting, diarrhea, sweating and, in some cases, convulsions, coma and death Copper is an element essential for many biological systems and plays an important role in carbohydrate and lipid metabolism. Toxic heavy metals are exposed to the natural ecosystem, accumulation of metal ions such as lead, cadmium and copper in the human body occurs through either direct intake or the food chain. Therefore, heavy metals should be prevented from reaching the natural environments because of their toxicity [30]. In natural aquatic ecosystems, metals occur in low concentrations, normally at the nanogram to microgram per liter level. In recent times however, the occurrence of metal contaminants especially the heavy metals in excess of natural loads has become a problem of increasing concern. This situation has arisen as a result of the rapid growth of population, increasing urbanization, industrial activities extension of irrigation, modern agricultural practices transport, burning of fossil fuels, animal and human excretion, geological weathering and domestic waste as well as the lack of environmental regulations [31].

\section{Heavy Metals in Fish Tissue}

Heavy metals are considered the hazardous inorganic and organic pollutants in the aquatic environment and their concentrations in the various parts of organisms are determined primarily indicative of the level of the pollution in the environment [32]. Heavy metal pollutants have become a global phenomenon because of its toxicity, persistence for several decades, nondegradable in the aquatic environment, bioaccumulation and bio magnification in the food chain [33]. Heavy metals can be classified as essential (copper, zinc, manganese and iron) since they play an important role in biological systems [34]. Potentially toxic (arsenic, cadmium, aluminum, lead and mercury [35]. The heavy metals can also produce toxic effects at high concentration and low or high trace element unbalances can be considered as 
risk factors for several diseases [36]. The heavy metals discharged into aquatic environmental (seas, rivers and lakes) can damage aquatic species, diversity and ecosystem. These toxic heavy metals have changed the quality of water that affects aquatic biota and fish. Fish in ponds, rivers and lakes can not avoid exposure to these toxic that suspended or dissolved in water, being less than land animals to move to favorable regions to avoid unfavorable conditions [37]. Transport of metals in fish occurs through blood and the metals are brought into contact with the organs and the tissues of the fish and consequently accumulated to different extents [38]. Prolonged exposures to trace elements even in very low concentrations have been reported to induce morphological, histological and biochemical alterations in the tissues that may critically influence fish quality [39]. Fish are integral components of aquatic ecosystems. In addition to being a source of high protein content and low saturated fat which contains omega fatty acids known to support good health [40], they play an important role in energy flows nutrient cycling and maintaining community balance in this ecosystem [41]. Bioaccumulation is an important process through which chemicals can affect living organisms. An increase in the concentrations of a chemical in a biological organism over time may occur compared to chemicals concentration in the environment. Bioaccumulation occurs when an organism absorbs a toxic substance at a rate greater than that at which the substance is lost. Bioaccumulation results from a dynamic equilibrium between exposure from the external environment and uptake, storage and extraction within an organism [42]. Fishes are considered as one of the most significant bio monitors in an aquatic system for the estimation of metal pollution concentration [43]. They offer several specific advantages in describing the natural characteristics of aquatic systems and in assessing changes observed in habitats [44]. Fishes are sensitive to any type of human disturbance such as industrial effluents, municipal waste, river discharge and strongly influence the distribution, migration, colonization of fishes [45]. In addition, fish are located at the end of the aquatic food chain and may accumulate metals and pass them to human beings through consumption causing chronic or acute diseases [46]. Fish are often the top of the aquatic food chain and accumulate large amounts of metals in their tissues to concentrations many times higher than present in water or sediment [47]. Also, fish may accumulate significant concentrations of metals even in water in which those metals are below the limit of detection in routine water samples [48]. Metals in natural waters occur in particulates or insoluble forms, including labile and non-labile fractions. The labile metal compounds are the most dangerous to fish. They include various ionic forms of different availability to fish. The amounts of metals in the labile fraction and the share of various metal ions strongly depend on environmental conditions [49]. Various metals are accumulated in the fish body indifferent amounts. These differences result from the different affinity of metals to fish tissues, different up take deposition and excretion [50]. Fish living in polluted water tend to accumulate heavy metals in their tissues. Generally, accumulation of heavy metal depends on metal concentration, time of exposure, a way of metal uptake, environmental conditions (water temperature, $\mathrm{pH}$, hardness and salinity). Also fish can absorb heavy metals through the epithelial or mucosal surface of the skin, gills and gastrointestinal tract [51]. Fish can regulate metal concentrations to a certain extent, after the occurrence of bioaccumulation [52]. Therefore, the ability of each tissue to either regulate or accumulate metals can be directly related to the total amount of metals accumulated in that specific tissue. Metal bioaccumulation by fish and subsequent distribution in organs is greatly inter-specific. In addition, many factors can influence metal uptake like sex, age, size, reproductive cycle, swimming patterns, feeding behavior and living environment (i.e., geographical location). When metals reach sufficiently high concentrations in body cells they can alter the physiological functioning of the fish [53]. The organisms developed a protective defense against the deleterious effects of essential and inessential heavy metals and other xenobiotics that produce degenerative changes like oxidative stress in the body [54].

\section{Biochemical Parameters of Fish Tissues}

Biochemical studies can be an available tool for identifying ecosystems contaminated by various pollutants or for following changes in such system through times [55]. Analysis of biochemical parameters could help to identify the target organs of toxicity as well as the general health status of animals. It may also provide an early warning signal in stressed organism [56]. Aquatic pollution can easily be detected through biomarkers, as biomarkers offer promise as sensitive indicators demonstrating that toxicants have entered organisms that have been distributed between tissues and are eliciting a toxic effect at critical targets. Biomarkers are measurable responses to the exposure of an organism to xenobiotics as well as very good biosensors of aquatic contaminants. Biomarkers are measurements in body fluids, cells or tissues indicating biochemical or cellular modifications due to the presence and magnitude of toxicants, or of host response [57]. Fish have been proposed as indicators for monitoring land-based pollution because they may concentrate indicative pollutants in their tissue, directly from water through respiration and also through their diet. Fish are frequently subjected to prooxidant effects of different pollutants often present in the aquatic environment [58].

\section{Total lipid, Triglycerides and total cholesterol}

Lipids are a diverse group of molecules that include monoglycerides, diglycerides, triglycerides, fats, sterols, and others. Not only do lipids define and preserve cellular membrane integrity, but they are also involved in cellular processes such as membrane trafficking, signal transduction, apoptosis, and energy storage. Total lipid is used as energy reservoir, stored and transported in the form of glycerol esters. Lipid plays an important fuel reserve of the fish during stress situation so glycogenolysis, proteolysis and hydrolysis of lipids have been reported to generate more energy through gluconeogenesis in order to cope with the increased energy demands occurring due to metal toxicity in fish [59]. 
Triglycerides are water-insoluble lipids consisting of three fatty acids esterifiedto a glycerol backbone. Triglycerides are transported in the blood as core constituents of all lipoproteins, but are major components of triglyceride-richchylomicrons and very low-density lipoproteins (VLDL) [60]. The measurements of triglyceride levels, in conjunction with other lipid assays, are useful in the diagnosis of primary and secondary hyperlipoproteinemia, dyslipidemia, and triglyceridemia. Triglyceride concentrations are also useful in the diagnosis and treatment of diabetes mellitus, nephrosis, liver obstruction, and other diseases involving lipid metabolism or various endocrine disorders [61]. Cholesterol is the major sterol in animal tissue. Cholesterol and its esters with long chain fatty acids are important components of plasma lipoprotein and of the outer cell membrane. It stimulates utilization of fatty acids and ketogenesis. Cholesterol is also important for the synthesis of bile acids, which facilitate the emulsification, and digestion of lipids in the small intestines [62]. Cholesterol belongs to one of a group of steroids compounds which have in common the basic phenanthrene derivative, although it is a precursor for sex steroid hormones in the gonads and is obtained normally from circulating low-density lipoprotein, it can be synthesis (denova) in the gonads from two carbon fragment Acetyl Co A [63]. Cholesterol is a critical compound used in the structure of cell membranes, hormones, and cell signaling. It is an essential component of animal cell structure in order to maintain permeability and fluidity. Cholesterol exists within a lipoprotein as a free alcohol and as a fatty cholesteryl ester, which is the predominant form of cholesterol transport and storage. Total lipid was formed by the cholesterol, phospholipids, and triglyceride and so the elevation in its components leads to the increase in total lipid [64]. The level of total lipids, triglycerides and total cholesterol in tissues of fish have been reported to be moderately sensitive to environmental pollutant but the direction of change in these parameters seems to be dependent on many factors, such as the types of contaminant, the concentration, mode of its action, duration of exposure and fish species [52]. Changes in these parameters generally reflect the state of the animal nutrition, endocrine function as well as integrity of the vital organs especially the liver and kidneys [65].

\section{Transaminases}

All chemical reactions in the cells are catalyzed by enzymes and introduction of foreign chemicals in the cell generally disturbed enzymes functions. Enzymes activities are considered as sensitive biochemical indicators before hazardous effects occur in fish, Changes in Enzymes activities in fish have been used frequently as indicators of intoxication and water pollution [66]. Transaminases are important enzymes known to play a key role in mobilizing L-amino acids for gluconeogenesis and function as links between carbohydrate and protein metabolism under altered physiological, pathological conditions [67]. ALT catalyses the transfer of the amino group from alanineto a-ketoglutarate to form glutamate and pyruvate while AST catalyses the transfer of the amino group from aspartate to a-ketoglutarate to form glutamate and oxaloacetate [68]. Alanine is a non-essential amino acid that plays a key role in the glucose-alanine cycle between muscle tissue and the liver. Aspartate, the carboxylate anion of aspartic acid, is an acidic, non-essential amino acid involved in protein synthesis and multiple other cellular biochemical pathways. Aminotransferase links carbohydrate and protein metabolism as it catalyzes their inter-conversion. The activities of these enzymes are directly proportional to the level of total protein and inversely proportional of cholesterol, an indication that the enzymes are catalyzing the inter-conversion of carbohydrate to protein in the liver [69]. Also, transaminases are biomarker enzymes endogenous in the liver responsible for the transformation of protein to glycogen [70]. ALT is the most specific enzyme for the liver.

\section{ALP activity}

Alkaline phosphatase (ALP) catalyzes the hydrolysis of a wide variety of physiologic and non-physiologic phosphoric acid esters in alkaline medium ( $\mathrm{p}^{\mathrm{H}}$ optimum 10). ALP is employed to assess the integrity of plasma membrane and endoplasmic reticulum. The liver and biliary tracts are the sources of alkaline phosphatase. ALP is one of the tests of choice for evaluating cholestasis and obstructive jaundice. Tissue distribution of alkaline phosphatase is virtually ubiquitous especially within cell membranes and would easily leak out of the cell in pollutants-induced tissue damage [71]. ALP is composed of sever alisoenzymesthatare present in practically all tissues of the body, especially in cell membranes. It catalyses the hydrolysis of monophosphate esters and has a wide substrate specificity [72].

\section{Oxidative stress parameters}

Oxidative stress is more often used as a biomarker of the effects of exposure to environmental pollution in aquatic environments. Antioxidants are defined as compounds that can inhibit or prevent the oxidation of oxidizable materials by scavenging free radicals and diminishing oxidative stress. Many pollutants (or their metabolites) may exerttoxicity related to oxidative stress. Several classes of pollutants, including trace metals and organic compounds, are known to enhance the formation of ROS resulting from xenobiotic redox cycling [73]. A battery of enzymes and molecules plays important roles in detoxifying xenobiotics and ROS, thus it has been applied as a biomarker for environmental risks in fish [74]. The use of a battery of biomarkers will provide a more complete picture of various effects on oxidative stress in the cells of an organism [73]. Oxygen toxicity is defined as injurious effects due tocytotoxic reactive oxygen species (ROS), also referred toas reactive oxygen intermediates (ROIs), oxygen free radicals or oxyradicals [75]. Fish as all other aerobic organisms generate endogenous reactive oxygen species (ROS) and other oxidants during aerobic metabolisms and energy production in the mitochondria. Under normal physiological status the antioxidant defense systems including SOD, CAT and GST can be induced by a slight oxidative as a compensatory response and thus the reactive oxygen species (ROS) can be removed to protect the organism from oxidative damage [76]. Pollutants with 
redox potential can produce increasing amount of ROS in aquatic organisms in polluted sites these ROS can trigger oxidative damage to proteins, nucleic acid and lipids [77]. These reduction products of molecular oxygen $\left(\mathrm{O}_{2}\right)$ are the superoxide anion radical $\left(\mathrm{O}_{2}\right.$ .), hydrogen peroxide $\left(\mathrm{H}_{2} \mathrm{O}_{2}\right)$ and the hydroxyl radical (OH.), an extremely potent oxidant scapable of reacting with critical cellular macromolecules, possibly leading to enzyme inactivation, lipid peroxidation (LPOX), DNA damage and, ultimately, cell death [78].

SOD and catalase activity: Superoxide dismutatase (SOD) and catalase (CAT) have been detected in a wide variety of mammalian cells. These enzymes play important roles in protecting the cell against the potentially toxic effects of environmental pollutants [79]. The level of antioxidant enzymes have been extensively used as an early warning indicator of lake pollution [80]. The SODs are a group of metalloenzymes that catalyse the conversion of reactive superoxide anions $\left(\mathrm{O}_{2}+\right)$ to yield hydrogen peroxide $\left(\mathrm{H}_{2} \mathrm{O}_{2}\right)$, which in itself is an important ROS as well. $\mathrm{H}_{2} \mathrm{O}_{2}$ is subsequently detoxified by two types of enzymes: CAT $^{\mathrm{s}}$ and glutathione-dependent peroxidases $\left(\mathrm{GPOX}^{\mathrm{s}}\right)$. SOD catalytically scavenges superoxide radical which appears to be an important agent of toxicity of oxygen and this provides a defense against this aspect of oxygen toxicity [81]. A unit of SOD activity is defined as the amount that causes $50 \%$ inhibition of the reduction of the scavenger under specified conditions. CAT $^{s}$ are hematin-containing enzymes that facilitate the removal of hydrogen peroxide $\left(\mathrm{H}_{2} \mathrm{O}_{2}\right)$, which is metabolized to molecular oxygen $\left(\mathrm{O}_{2}\right)$ and water [74]. Unlike some peroxidases that can reduce various lipid peroxides as well as $\mathrm{H}_{2} \mathrm{O}_{2}$, CATs can only reduce $\mathrm{H}_{2} \mathrm{O}_{2}$ [82]. It was demonstrated that peroxi some proliferating compounds (a class of nongenotoxiccarcinogens) induce both the activities of $\mathrm{H}_{2} \mathrm{O}_{2}$-generating fatty acid oxidizes and CAT in rodents [83]. CAT and GST enzymes have been used as parameters to assess environmental pollutant contamination in fish tissues [84]. The liver in fish is an organ that performs various functions associated with the metabolism of xenobiotics [85]. SOD and CAT enzymes are linked functionally and occur in tandem [86].

\section{Total protein concentration}

Protein is an important constituent of all the cells and tissues as it plays a vital role in the physiology of living organisms. Since fishes have very little carbohydrates, proteins invariably are used in fish to meet energy demands also [87]. Proteins are involved in major physiological events, therefore, the assessment of the protein content can be considered as a diagnostic tool to determine the physiological phase of an organism and proteins are highly sensitive to heavy metal poising [88-90]. The variation in protein distribution suggests a gradual difference in metabolic calibres of various tissues and it is a physiological strategy adopted by the animal to adjust itself to the changing metabolic system [62].

\section{Acknowledgement}

None.

\section{Conflict of Interest}

No conflict of interest.

\section{References}

1. Ozedn O (2010) Micro, micro minerals and proximate composition of Atlantic bonito and horse mackerel a monthly differentiation. Int J food Sci Technol 45: 578-586.

2. Gary S, Gupta Rk, Jain KL (2009) Sub lethal effects of heavy metals on biochemical composition and their recovery in indian major carps. J Hazard Mates 163: 1369-1384.

3. Moja SJ (2007) Manganese fractions and Distributions in Street Dust and Roadside Soils from Tshwane, South Africa, Ph-D thesis. Tshwane University of Technology SA.

4. Azhar S, Abdul-Razak M, Abdul A, Haider A, Bahram M (2011) On the Current and Restoration Conditions of the Southern Iraqi Marshes: Application of the CCME WQI on East Hammar Marsh. Journal of Environmental Protection (2): 316-322.

5. Poonam T, Tanushree B, Sukalyan C (2013) Water quality indicesimportant tools for water quality assessment: a review. Int J Adv Chem (IJAC) 1(1): 15-28.

6. Bharti N, Katyal D (2011) Water quality indices used for surface water vulnerability assessment. Int J Environ Sci 2 (1): 154-173.

7. Ezra A, Nwankwo D (2001) Composition of phytoplankton algae in Gubi reservoir, Bauchi, Nigeria. Journal of Aquatic Sciences 16 (2): 115-118.

8. Mary I, John F, Steven D, Benjamin S, sarah E, et al. (2007) Temperature control of larval dispersal and the implication for marine ecology, evolution and conservation. PNAS 104: 1266-1271.

9. Civera I, Gil R, Laguarda, Miro N, Garcia Breigo E (2011) Instrument for sunlight extinction measurement in water bodies, sensors and Actuators, A:186 : 267-274.

10. Luettich Jr, Harleman DR, Somlyody L (1990) Dynamic behaviour of suspended sediment concentrations in a shallow Lake perturbed by episodic wind events. Limnol Oceanogr 35: 1050-1067.

11. Kayima J, Kyakula M, Komakech W, Echimu S (2008) A study of the degree of Pollution in Nakivubo Channel, Kampala, Uganda. J Appl Sci Environ Manage 12(2): 93-98.

12. Amir E, Fardin B, Omid T, Mousad H (2011) An assesement of water pollution of the beshar river. Aquatic Ecosystem world academy of science Engineering and Technology.

13. ANZECC (Australian and New Zealand Environment Conservation Council) (2000) Australian and new Zealand Guidelines for fresh and marine water quality. Australian and New Zealand Environment and Conservation Council.

14. Vaquer-Sunyer R, Duarte CM (2008) Thresholds of hypoxia for marine biodiversity. Proc Nat Acad Sci 105(40): 15452-15457.

15. USEPA (United States Environmental Protection Agency) (2001) Nutrient Criteria Technical Guidance Manual - Estuarine and Coastal Marine Waters. Office of water, Washingtone DC, USA.

16. Joan E, Merryl A (2011) Recommended indicators of estuarine water quality for Georgia. proceedings of the 2011 Georgia water Resources Conference, held April 11-13, At the university of Georgia.

17. Conly D (2000) Biogeochemical nutrient management strategies. Hydrobio 41: 87-96.

18. Galloway JN, Townsend AR, Erisman JW, Bekunda M, Cai Z et al. (2008) Transformation of the nitrogen cycle: recent trends, questions, and potential solutions. Science 320(5878): 889-892.

19. Smith P, Ashmore M, Black H, Burgess PJ, Evans C, et al. (2013) The role of ecosystems and their management in regulating climate, and soil, water and air quality. J Appl Ecol 50: 812-829.

20. Clark, RB (2001) Metals. In: Marine pollution. Oxford University Press, Oxford (5 ${ }^{\text {th }}$ Ed.) pp: 98-125.

21. Gad NS, Toufeek MA (2010) Distribution and accumulation of some trace metals in water and fish from Damietta Branch of River Nile. African j Bio Sci 6(1): 95-115. 
22. McNeil DG, Fredberg J (2011) Environmental water requirements of native fishes in the Middle River catchment, Kangaroo Island, South Australia. A Report to the SA Department for water. South Australian Research and Development Institute (Aquatic sciences), Adelaide. p 50.

23. Cavas T (2008) In vivo genotoxicity of mercury chloride and lea acetate: micronucleus test on acridine orange stained fish cells. Food Chem Toxicol 46(1): 352-358.

24. Ibrahim HS, Ibrahim MA, Samhan FA (2009) Distribution and bacterial bioavailability of selected metals in sediments of IsmailiaCanal, Egypt. J Hazard Mater 168: 1012-1016.

25. Güven DE, Akinci G (2008) Heavy metals partitioning in the sediments of Izmir Inner Bay. J Environ Sci-China 20(4): 413-418.

26. Kotze P, DuPreez HH, VanVuren JHJ (1999) Bioaccumulation of copper and zincin Oreoc hromism ossambic us and Clariasgariepinus, from the Oli fants River, Mpumalanga, South Africa. Water SA 25(1): 99-110.

27. Storelli MM, Storelli A, D'ddabbo R, Marano C, Bruno R et al. (2005) Trace elements in loggerhead turtles (Carettacaretta) from the eastern Mediterranean Sea: Overview and evaluation. Environ Pollut 135(1): 163-170.

28. Mendil D, Uluözlü OD (2007) Determination of trace metal levels in sediment and five fish species from lakes in Tokat, Turkey. Food Chemistry 101: 739-745.

29. Censi P, Spoto SE, Saiano F, Sprovieri M, Mazzola S, et al. (2006) Heavy metals in coastal water systems. A case study from the northwestern Gulf of Thailand. Chemosphere 64(7): 1167-1176.

30. Shirkhanloo H, Zavvar H, Rouhollahi A (2011) Preconcentration and determination of heavy metals in water, sediment and biological samples. J Serb Chem Soc 76 (11) 1583-1595.

31. FAO (1992) Committee for inland fishers of Africa; Working Party on Pollution and Fishers.FAO Fish .Rep. No. 471.

32. Sivakumar R, Natesan M (2011) Impact of metals on histopathology and expression of HSP 70 in different tissues of Milk fish (Chanos chanos) of Kaattuppalli Island, South East Coast, India. Chemosphere 83(4): 415421.

33. Yi Y, Yang Z, Zhang S (2011) Ecological risk assessment of heavy metals in sediment and human health risk assessment of heavy metals in fishes in the middle and lower reaches of the Yangtze River basin. Environ Pollution 159(10): 2575-2585.

34. Rutkiewiez I, Namiesnik S (2009) Urine as a source of information on occupational exposer to metals, a review. Ecol Chem Eng Sci 16: 63 - 80.

35. Ganjavi M, Ezzatpanah H, Givianrad M, Shams A (2010) Effect of canned tuna fish processing steps on lead and cadmium contents of Iranian tuna fish. Food Chem 118: 525-528.

36. He Z, Song J, Zhang N, Zhang P, Xu Y (2009) Variation characteristics and ecological risk of heavy metals in the south yellow sea surface sediments. Environ Monit Assess 157(1-4): 515-528.

37. Gad NS (2009) Determination of glutathion related enzymes and cholenisterase activities in Oreochromisniloticus and clariasgariepinus as bioindicator for pollution of lake Manzala. Global Veterinaria 2 (1): 37-44.

38. Kalay M, Canli M (2000) Elimination of Essential ( $\mathrm{Cu}, \mathrm{Zn}$ ) and Nonessential $(\mathrm{Cd}, \mathrm{Pb})$ Metals from Tissues of a Fresh Water Fish, Tillapiazilli. Turk J Zool 24: 429-436.

39. Kaoud HA, El-Dahshan AR (2010) Bioaccumulation and Histopatho logical Alterations of the Heavy Metals in Oreochromis Niloticus Fish. Nature and Science 8 (4): 147-156.

40. Ikem A, Egiebor N (2005) Assessment of trace element in canned fish (Mackel, tuna, salamon, sardines and herrings) marketed in Georgia and Alabama. United states of American Journal of Food Composition and Analysis 18: 771-787.

41. Chari KB, Abbasi SA (2005) A study on fish fauna of oussudu. A rale fresh water lake of south india. Intern J Environmentalstudi 62: 137-145.
42. Zhou R, Zhu L, Chen Y, Kong Q (2008) Concentrations and characteristics of organochlorine pesticides in aquatic biota from Qiantang River in China. Environ Pollut 151(1): 190-199.

43. Begum A, Amin Md N, Kaneco A, Ohta K (2005) Selected elemental composition of the muscle tissue of three species of fish, Tilapia nilotica, Cirrhinamrigala and Clariasbatrachus, from the fresh water Dhanmondi Lake in Bangladesh. Food Chem 93: 439-443.

44. Lamas S, Fernàndez JA, Abdal JR, Carballeira A (2007) Testing the use of Juvenile Salmotrtta L as biomonitors of heavy metal pollution in fresh water. Chemosphere 67: 221-228.

45. Plafkin JL, Barbour MT, Porter KD, Gross SK, Hughes RM (1989) Rapid bio assessment protocols for use in streams and rivers: Benthic macro vertebrates and fish. Environmental protection Washington DC, USA 440: 4-89.

46. Al-Yousuf MH, El-Shahawi, Al-Ghais SM (2000) Trace metals in liver, skin and muscle of Lethrimus lentjan fish species in relation to body length and sex. The science of the total Environment 256(2-3): 87-94.

47. Olaifa F, Olaifa A, Adelja A, Owolabi A (2004) Heavy metals contamination in clariasgariapinus from alake and fish farm in Ibadan, Nigeria African. J Bio med res 7: 145- 148.

48. Mohamed FAS (2008) Bioaccumulation of selected metals and Histopatho logical Alterations in tissues of Oreochromisniloticus and latesniloticus from lake Nasser, Egypt. Global veterinaria 2 (4): 205-218.

49. Cogun HY, Kargin F (2004) Effects of PH on themortality and accumulation of copper in tissues of Oreochromisniloticus. Chemosphere 55: 277-282.

50. Jezierska B, Witeska M (2001) Metal toxicity to fish. Wydawinctwo Akademii Podlaskiej Siedlce p.318.

51. Jovanovic B, Mihaljev E, Maletin S, Palic D (2011) Assesement of heavy metal load in chub liver (Cyprinida. leuciscuscephalus). from the Nisava river (Serbia) Biol Nyssana 2 (1): 1-7.

52. Heath AG (1995) Water pollution and fishphysiology. (2nd edn.) Lewis Publisher. New York and London p.359.

53. Heath AG (1987) Water Pollution and Fish Physiology. CRC Press Inc Boca Ranton Florida USA p.245.

54. Filipovic V, Raspor B (2003) Metallothionein and metal levels in cytosol of liver, kidney and brain in relation to growth parameters of Mullussurmuletusand Liza aurata. From the eastern Adriatic Sea Water Res 37(13): 3253-3262.

55. Mansour SA, Sidky MM (2003) Ecotoxicological studies. 6. The first comparative study between Lake Qarun and Wadi El-Rayan Wetland (Egypt), with respect to contamination of their major components. Food Chem 82: 181-189.

56. David MH, Ramesh V, patil S, Marigoudar, Chetti S (2010) Sodium cyanide - induced modulations the activities of some oxidative enzyme and metabolites on the fingerlings C. carpio. Toxicalogical and Environment chemistry 92: 1841 -1849.

57. Sadati F, Shahsavani D, Baghshani H (2013) Biochemical alterations induced by sublethal cyanide exposure in common carp (Cyprinuscarpio). J Biol Environ Sci 7(20): 65-69.

58. Velkova-Jordanoska L, Kostoski G, Jordanoska B (2008) Antioxidative enzymes in fish as biochemical indicators of aquatic pollution. Bulg J Agric Sci 14: 235-237.

59. Rathod DS, Lokhande MV, Shembekar VS (2009) Toxic impact on the biochemical composition of vital tissues of fish, Arias dussumieri. Shodh Samiksha and Mulyankan 2: 147-149.

60. Cole TG, Klotzsch SG, McNamara JR (1997) Measurement of Triglyceride Concentration in Handbook of Lipoprotein Testing. Rifai N, et al., Ed. AACC Press. Washington DC, USA.

61. Rifai N, Bachorik, PS, Albers JJ (2001) Lipids, Lipoproteins, and Apolipoproteins in Tietz Fundamentals of Clinical Chemistry. Burtis CA, Ashwood ER, Ed. WB Saunders Company, Philadelphia, PA, pp.462-493. 
62. Mir AH (2015) impact of anthropogenic activities on the biochemical parameters of labeocalbasucaught from betwa river in raisendistrict(m.p). Indian Streams Research Journal 5: 1-5.

63. Gad NS (1999) Bioassay studies for assessment of some pesticide on Tilapia zilli living in fresh and saline water ph. D. Thesis departmente of biochemistry Fac. Of Sci Ain -Shams Uni P.223.

64. Javed M, Usmani N (2015) Stress response of biomolecules (carbohydrate, protein and lipid profiles) in fish Channa punctatus inhabiting river polluted by Thermal Power Plant effluent. Saudi Journal of Biological Sciences 22(2): 237-242.

65. Zubay G (1993) Biochemistry Third edition Wm. C. Brown publishers, lowuOxifo.

66. Kim SG, Park SW, Jang GS, Lee SS, Kim, et al. (2008) effect of dietary Benzopyrene on growth and nematological parameters in guvenile Rock fish, subustesschlegeli Bull, Environ. Cont Toxical 81: 470 - 474.

67. Manjunatha B, Tirado J, Selvanayagam M (2015) Sub-lethal toxicity of potassium cyanide on Nile Tilapia (Oreochromisniloticus): Biochemicalresponse. International Journal of Pharmacy and Pharmaceutical Sciences 7(3): 379-382.

68. Moss DW, Henderson AR, Kochmar JF (1986) Enzymes; principles of diagnostic enzymology and the aminotransferases. In: Tietz NW (Ed.), Textbook of Clinical Chemistry. Saunders Philadelphia PA pp. 663-678.

69. Martin DW, Mayers PA, Rodwell VW (1983) Harper's Review of Biochemistry. Lange Medical Publication Maruzen Asia.

70.Abou El-Naga EH, El-Moselhy KM, Hamed MA (2005) Toxicity of cadmium and copper and their effect on some biochemical parameters of Mugilseheli. Egyptian Journal of Aquatic Research 31(2): 60-71.

71. Sabae ZS, Mohamed AS (2015) Effect of Environmental Pollution on the Health of Tilapia spp. from Lake Qarun Global Veterinaria 14(3): 304328.

72. Vinodhini R, Narayanan M (2008) Effect of heavy metals induced toxicity on metabolic bio markers in common carp (CyprinuscarpioL). Maejo International Journal of Science and Technology 2(1): 192-200.

73. Carney Almroth B, Sturve J, Stephensen E, Fredrik Holth, Förlin L (2003) Protein carbonyls and anti oxidative defenses in corkwing wrasse (Symphodusmelops) from a heavy metal polluted and PAH polluted site. Mar Environ Res 66: 271-277.

74. Van der Oast R, Beyer J, Vermeulen NP (2003) Fish bioaccumulation and biomarkers in Environmental risk assessment: a review. Environ Toxicol Pharmacol 13(2): 57-149.

75. Winzer K (2001) Oxidative stress in the marine environment prognostic tools for toxic injury in fish liver cells. Academic Thesis University of Amsterdam.
76. Livingstoone DR (2001) Contaminant stimulated reactive oxygen species production and oxidative damage in aquatic organisms. Mar Pollution Bull 42(8): 656-666.

77. Atli G, Canli M (2007) Enzymatic responses to metal exposures in a freshwater fish Oreochromisniloticus. Comp Bioch Physiol C 145(2): 282-7.

78. Winston GW, Di Giulio RT (1991) Prooxidant and antioxidant mechanisms in aquatic organisms. Aquat Toxicol 19: 137-161.

79. Kuthan H, Haussmann HJ, Werringlover J (1986) A spectrophotometric assay for superoxide dismutase activities in crude tissue fractions. Biochem J 237(1): 175-180.

80. Lin CT, Lee TL, Duan KJ, Su JC (2001) Purification and Characterization of Black Porgy Muscle Cu/Zn Superoxide Dismutase. Zoological Studies 40(2): 84-90.

81. Kadar E, Costa V, Santos RS (2005) Distribution of micro-essential (Fe, $\mathrm{Cu}, \mathrm{Zn})$ and toxic( $\mathrm{Hg})$ metals in tissues of two nutritionally distinc thydrothermal shrimps. Sci Total Environ 358(1-3): 143-150.

82. Filho DW (1996) Fish antioxidant defences - a comparative approach. Braz J Med Biol Res 29(12): 1735-1742.

83. Halliwell B, Gutteridge (1999) Free Radicals in Biology and Medicine third ed. Oxford University Press Oxford UK.

84. Moraes BS, Loro VL, Glusczak L, Pretto A, Menezes C, et al (2007) Effects of four rice herbicides on some metabolic and toxicology parameters of teleost fish (Leporinus obtusidens). Chemosphere 68(8):1597-1601.

85. Jiminez BD, Stegeman JJ (1990) Detoxification enzymes as indicators of environmental stress on fish. Am Fish Soc Symp 8: 67-79.

86. Halliwall B (1994) Free radicals and antioxidant A personal view. Nutr Rev 52 (8 pt 1): 253-265.

87. Adamu KM, Kori-Siakpere O (2011) Effects of sublethal concentrations of tobacco (Nicotianatobaccum) leaf dust on some biochemical parameters of hybrid cat fish (Clariasgariepinus and Heterobranchusbidorsalis). Braz Arch Biotechnol 54(1): 183-196.

88. Jacob F (1977) Evolution and tinkering. Science 196(4295): 1161-1166.

89. Camusso M, Vigano L, Baitstrini R (1995) Bioaccumulation of trace metals in rainbow trout. Ecotox Environ Safe 31(2): 133-141.

90. Kotze P, DuPreez HH, VanVuren JHJ (1999) Bioaccumulation of copper and zincin Oreoc hromism ossambic us and Clariasgariepinus, from the Oli fants River, Mpumalanga, South Africa. Water SA 25(1): 99-110. 